Vietnam Academy of Science and Technology
Vietnam Journal of Earth Sciences
http://www.vjs.ac.vn/index.php/jse

\title{
Study on active tectonic faults using soil radon gas method in Viet Nam
}

Pham Tich Xuan, Nguyen Van Pho, Vu Van Chinh, Pham Thanh Dang, Nguyen Thi Lien, Doan Thu Tra, Hoang Tuyet Nga, Bui Van Quynh, Nguyen Van Luan, Nguyen Xuan Qua

Institute of Geological Sciences, Vietnam Academy of Science and Technology

Received 23 December 2015. Accepted 20 January 2017

\begin{abstract}
This paper presents the results of soil radon gas measurement in three areas, including Thac Ba and Song Tranh 2 hydropower plants, and the planned locations of the nuclear power plants Ninh Thuan $1 \& 2$ using solid-state nuclear track detectors (SSNTD) with the aim of clarifying the activity of tectonic faults in these areas. The activity of tectonic faults was assessed through radon activity index KRn (the ratio between anomaly and threshold), which was divided into 5 levels as follows ultra-high $\left(K_{R n}>10\right)$, high $\left(10 \Psi_{R n}>5\right)$, high $\left(5 \nVdash_{R n}>3\right)$, medium $\left(3 \nVdash_{R n}>2\right)$ and low $\left(\mathrm{K}_{\mathrm{Rn}} \mathcal{S}\right)$. Soil radon gas measurement results showed that in the radon gas concentrations in the Thac Ba hydropower plant area ranged from $72 \mathrm{~Bq} / \mathrm{m}^{3}$ to $273.133 \mathrm{~Bq} / \mathrm{m}^{3}$ and maximum radon activity index $\mathrm{K}_{\mathrm{Rn}}$ reached 9.75 (high level). High $\mathrm{K}_{\mathrm{Rn}}$ indexes show Chay River fault active in recent time and the sub-meridian distribution of Rn anomalies suggested a right-slip motion of the fault. Rn concentrations in the Ninh Thuan $1 \& 2$ areas ranged from $6 \mathrm{~Bq} / \mathrm{m}^{3}$ to $52.627 \mathrm{~Bq} / \mathrm{m}^{3}$, however, the $\mathrm{K}_{\mathrm{Rn}}$ indexes were mostly low $\left(\mathrm{K}_{\mathrm{Rn}} \mathfrak{3}\right)$ and the highest value was only 3.42 , suggesting that expression of activity of the tectonic faults in this region is not clear, even no expression of fault activity. In the Song Tranh 2 hydropower plant and adjacent areas, radon concentrations ranged from $29 \mathrm{~Bq} / \mathrm{m}^{3}$ to $77.729 \mathrm{~Bq} / \mathrm{m}^{3}$ and maximum $\mathrm{K}_{\mathrm{Rn}}$ index was 20.16 (ultra-high level). The faults having clearer activity expression are Hung Nhuong - Ta $\mathrm{Vy}$, Song Tra Bong and some high order faults, especially the northwest - southeast segments of these faults or their intersections with the northwest - southeast faults. In addition, the high values $\mathrm{K}_{\mathrm{Rn}}$ in the mentioned intersections can be evidenced for the activeness of northwest - southeast faults at the present time. The studies on active faults using soil radon gas method were performed in areas with very different geological and structural features, but the results are well consistent with the results of previous investigations obtained by other methods. It confirmed the effectiveness and capability of soil radon gas geochemistry applying to study active tectonic faults.
\end{abstract}

Keywords: Radon, Active Fault, Radon activity index, Thac Ba, Song Tranh 2, Ninh Thuan.

(C)2017 Vietnam Academy of Science and Technology

\section{Introduction}

The elevation of radon $(\mathrm{Rn})$ concentration in soil gas is known to be associated with

"Corresponding author, Email: Email: tichxuan@ gmail.com seismic activity and the movement of tectonic faults. The relationship between the change in concentration of $\mathrm{Rn}$ in soil gas and activity of tectonic faults has been an object of interest of many geologists and used to detect, identify 
and locate active faults (King et al., 1996; King, 1978; Al-Hilal and Al-Ali, 2010; Amponsah et al., 2008; Asumadu-Sakyi et al., 2010; Baubron et al., 2002; Burton et al., 2004; Font et al., 2008; González-Díez et al., 2009; Haerudin et al, 2013; Ioannides et al., 2003; Israel and Bjornsson, 1967; Lombardi and Voltattorni, 2010; Papastefanou, 2010; Seminsky and Demberel, 2013; Swakon et al., 2004; Tanner, 1980; Utkin and Yurkov, 2010; Walia et al, 2008). Since then, soil radon gas geochemistry is considered as a quantitative method to study active faults. In addition, monitoring of radon concentration change is also widely used as a tool to predict earthquakes (Wakita et al., 1980; Hauksson, 1981; Toutain and Baubron, 1999; Ghosh et al., 2009; Laskar, et al., 2011; Wang et al., 2014; Riggio et al., 2015).

In Vietnam, the soil radon gas method has been effectively applied in the assessment of active faults in some areas such as Northwest and south- Central regions, Thac $\mathrm{Ba}$, Son La... (Nguyen Van Pho et al., 1996a, b, 1999, 2004; Tran Van Duong, Tran Trong Hue, 1996; Tran Trong Hue, 1996, 1999). More recently, Rn measurements had been carried out by authors in the expected sites of nuclear power plants in Ninh Thuan province (20122013) and hydropower plant Song Tranh 2 area, Quang Nam province (2014).

This paper presents some results of soil gas radon measurements in Ninh Thuan, Thac $\mathrm{Ba}$ and Song Tranh 2 hydropower plants.

\section{Study areas}

Radon measurements had been carried out in 3 areas, including Thac $\mathrm{Ba}$ and Song Tranh 2 hydropower plants, and planned sites of nuclear power plants Ninh Thuan $1 \& 2$ (Figure 1).

\subsection{Thac Ba hydropower plant area}

Thac $\mathrm{Ba}$ hydropower reservoirs are on Chay River, located in the Yen Binh District,
Yen Bai Province. The study area is located at the southeastern end of hydropower reservoirs.

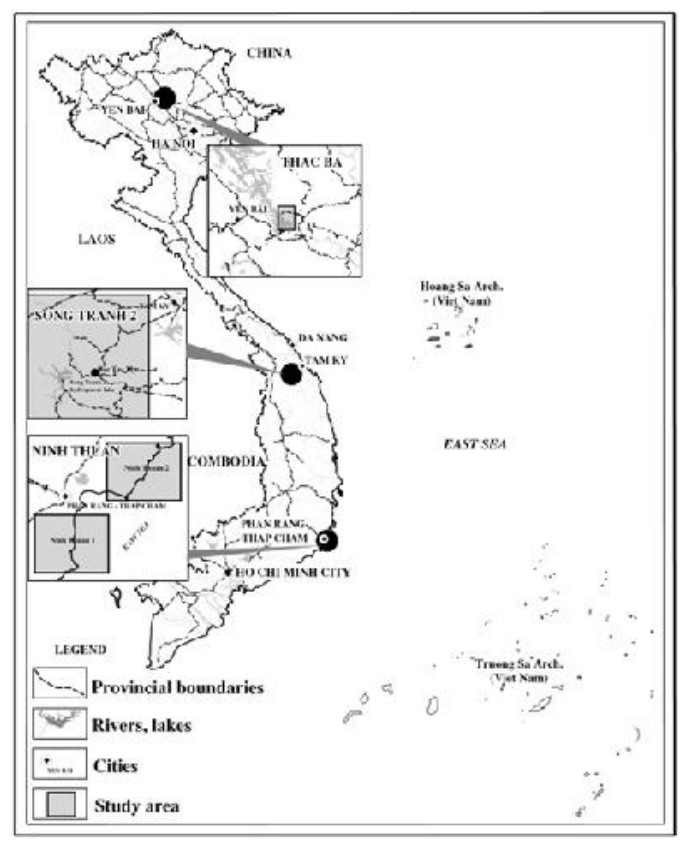

Figure 1. Location of study areas

Thac Ba hydropower area and adjacent are composed of Proterozoic - Cambrian metamorphic rocks, Paleozoic terrigenous - carbonate, Neogene terrigenous sediments and Quaternary unconsolidated sediments (Figure 2). The Proterozoic - Cambrian rocks include gneiss, amphibolite, schist, quartzite and marble of Nui Con Voi (PR1 nv), Ngoi Chi ( $\mathrm{PR}_{1}$ $n c)$, Thac $\mathrm{Ba}\left(\mathrm{PR}_{3^{-}}{ }_{1} t b\right)$ and $\mathrm{Ha}$ Giang ( 2 $h g$ ) formations. Paleozoic terrigenous - carbonate sediments include marble, sericite schist, sandy siltstone, shale and limestone of Phia Phuong $\left(\mathrm{D}_{1} p p\right)$, Song Mua $\left(\mathrm{D}_{1} s m\right)$, Ban Nguon $\left(\mathrm{D}_{1} b n\right)$, and Mia Le Formation $\left(\mathrm{D}_{1}\right.$ $m l)$. Neogene terrigenous sediments contain conglomerate, gritstone, quartz sandstone, siltstone and coal seams of Phan Luong $\left(\mathrm{N}_{1} p l\right)$ and Co Phuc $\left(\mathrm{N}_{1} c p\right)$ formations. Quaternary sediments include pebble, gravel, sand, clay... spread along rivers and streams. 


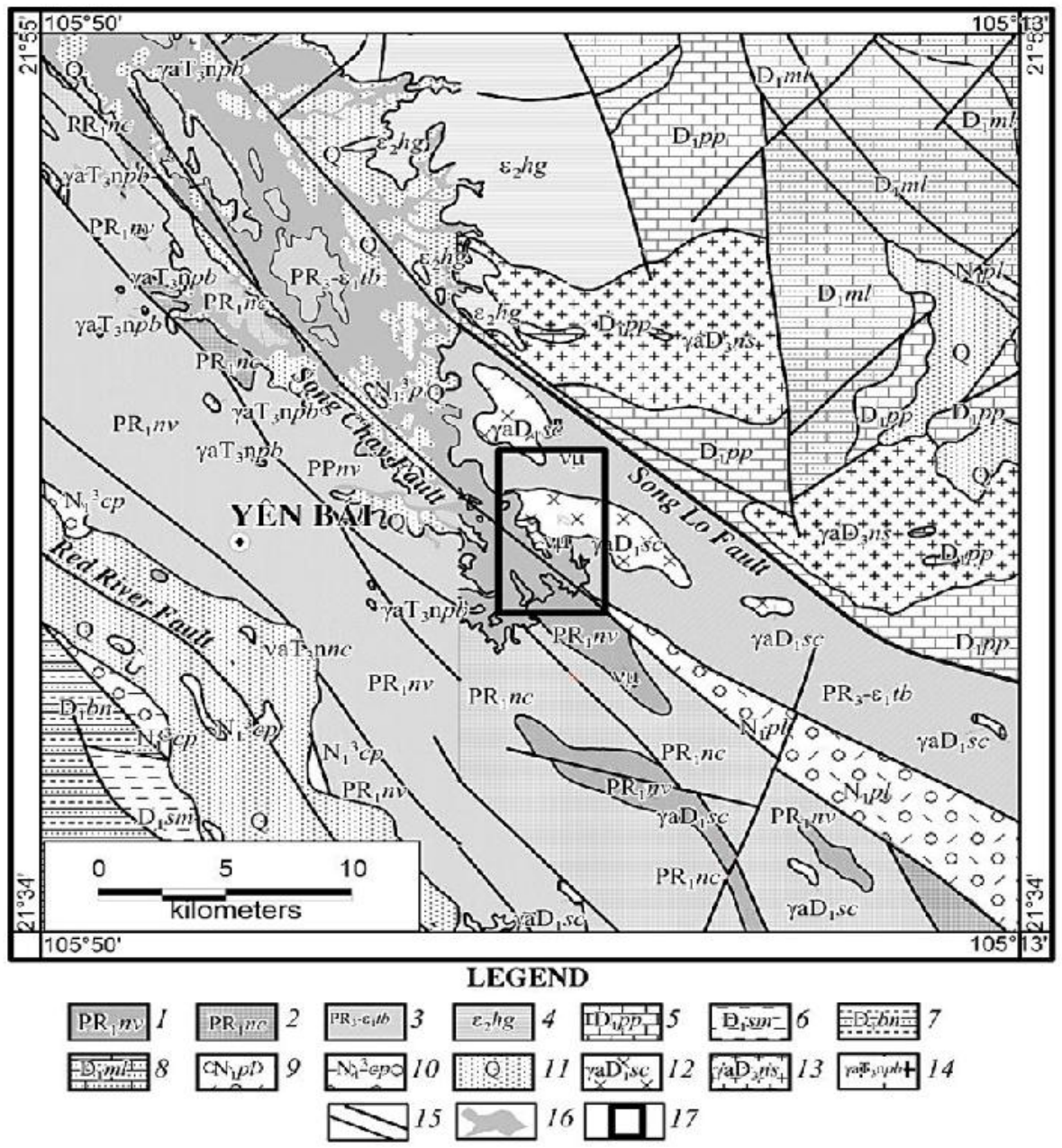

Figure 2. Geological map of Thac Ba hydropower plant area and adjacent (modified from Geological and Mineral Resources Map of Vietnam on 1:200,000, 2005)

1. Nui Con Voi formation: $\left(\mathrm{PR}_{1} n v\right)$; 2. Ngoi Chi formation $\left(\mathrm{PR}_{1} n c\right)$; 3. Thac Ba formation $\left(\mathrm{PR}_{3^{-}}{ }_{1} t b\right)$; 4. Ha Giang formation ( $\left.{ }_{2} h g\right)$; 5. Phia Phuong formation $\left(\mathrm{D}_{1} p p\right)$; 6. Song Mua Formation $\left(\mathrm{D}_{1} s m\right)$; 7. Ban Nguon Formation $\left(\mathrm{D}_{1}\right.$ $b n)$; 8. Mia Le Formation $\left(\mathrm{D}_{1} m l\right)$; 9. Phan Luong Formation $\left(\mathrm{N}_{1} p l\right)$; 10. Co Phuc Formation $\left(\mathrm{N}_{1} c p\right)$; 11. Quaternary sediments; 12. Granite Song Chay Complex $\left(\gamma \mathrm{aD}{ }_{1} s c\right) ; 13$. Granite Ngan Son Complex $\left(\gamma \mathrm{aD}_{1} n s\right)$; 14. Phia Bioc Complex $\left(\gamma \mathrm{aT}_{2} \mathrm{n} p b\right) ; 15$. Faults; 16. Lake; 17. Study area

Intrusive rocks are mainly granitoids including granodiorite-gneiss, porphyritic granitogneiss, biotite granite, pegmatite, aplitic granite of Song Chay Complex $\left(\mathrm{aD}_{1} s c\right)$; biotite granite, two-mica granite, aplite, pegmatite of Ngan Son Complex $\left(\mathrm{raD}_{1} n s\right)$ and porphyritic aluminium-rich biotite granite, medium- to fine-grained granite, leucocratic granite, aplite, pegmatite, quartz-tourmaline veins of Phia Bioc Complex $\left(\gamma_{\mathrm{a}} \mathrm{T}_{2} \mathrm{n} p b\right)$.

The main fault systems in the area are Red River, Da River and Lo River Faults running parallel in the northwest - southeast direction along with their accompanying minor faults. 
Pham Tich Xuan, et al./Vietnam Journal of Earth Sciences 39 (2017)

These are deep zoning faults considered as active in recent time. Also, sub-meridian and northeast - southwest faults are also well developed in the area. The main dams of hydropower reservoirs are built within the Song Chay fault zone, dam No. 9, especially is located directly on the fault line (Figure 2).

\subsection{Song Tranh 2 hydropower plant area}

In the Song Tranh 2 hydropower plant area, the studies had been carried out in the large area of Bac Tra My, Tien Phuoc and Hiep Duc districs (Quang Nam province) (Figure 1).

Song Tranh 2 hydropower plant area and adjacent regions on the northern edge of the

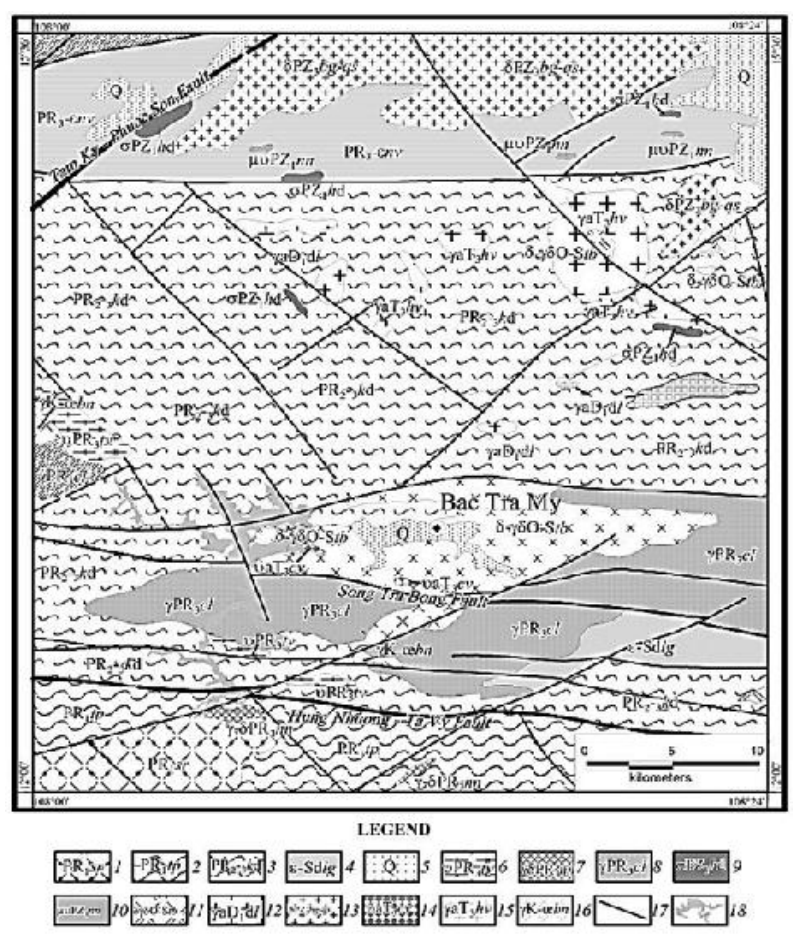

Kontum massive and compose of Proterozoic and Early Paleozoic metamorphic rocks, Quaternary sediments and numerous of intrusive rocks (Figure 3). The Proterozoic rocks include gneiss and plagiogneiss, amphibolite, crystalline schist, graphite-bearing schist, olivine and dolomitic marble of Song $\operatorname{Re}\left(\mathrm{PR}_{1}\right.$ $s r)$, Tac $\mathrm{Po}\left(\mathrm{PR}_{1} t p\right)$, Kham Duc $\left(\mathrm{PR}_{2-3} k d\right)$. Early Paleozoic rocks consist of sericite schist, quartz-sericite schist, marble of Dak Long Formation ( $-\mathrm{S}$ dlg). Along the rivers and streams occurred Quaternary unconsolidated sediments including pebbles, gravel, gravelly sand, clay, dough.

$\leftarrow$ Figure 3. Geological map of Song Tranh 2 hydropower plant area and adjacent (modified from Geological and Mineral Resources Map of Vietnam on 1:200,000, 2005)

1. Song Re Formation $\left(\mathrm{PR}_{1} s r\right)$; 2. Tac Po Formation $\left(\mathrm{PR}_{1} t p\right)$; 3. Kham Duc Formation $\left(\mathrm{PR}_{2-3} k d\right)$; 4. Dak Long Formation ( -S dlg); 5. Quaternary sediments; 6. Ta Vy Complex $\left(v \mathrm{PR}_{3} t v\right)$ : Gabbroamphibolite; 7. Nam Nin Complex $\left(\gamma-\delta \mathrm{PR}_{3} n n\right)$ : Plagiogranitogneiss; 8. Chu Lai Complex $\left(\gamma \mathrm{PR}_{3} c l\right)$ : granitogneiss; 9. Hiep Duc Complex $\left(\sigma \mathrm{PZ}_{1} h d\right)$ : Ultramfic rocks; 10. Nui Ngoc Complex ( $\left.v \mathrm{PZ}_{1} n n\right)$ : Gabbro, gabbrodiabas; 11. Tra Bong Complex $(\delta-\gamma \delta \mathrm{O}-\mathrm{S} t b)$ : Diorite, granodiorite; 12. Dai Loc Complex $\left(\gamma \mathrm{aD}_{1} d l\right)$ : Gneissogranite, granite; 13. Ben Giang - Que Son Complex $\left(\gamma \xi \mathrm{PZ}_{3} b g-q s\right)$ : Diorite, granodiorite; 14 . Cha Val Complex $\left(v_{a T} c v\right)$ : Gabbropyroxenite; 15. Hai Van Complex $\left(\gamma \mathrm{aT}_{3} h v\right)$ : Granite; 16. Ba Na Complex $(\gamma \mathrm{K}-\mathrm{E} b n)$ : Leucogranite, alaskite; 17. Faults; 18. Lake

The intrusive rocks are widely spread and varied, including gabbroamphibolite of $\mathrm{Ta} \mathrm{Vy}$ Complex $\left(v \mathrm{PR}_{3} t v\right)$; plagiogranitogneiss, tonalitogneiss of Nam Nin Complex $\left(\gamma-\delta \mathrm{PR}_{3}\right.$ $n n)$; granite-gneiss, migmatite granite, garnetbiotite granite, two-mica gneiss-granite, peg-

matite, aplite of Chu Lai Complex $\left(\gamma \mathrm{PR}_{3} c l\right)$; serpentinized, carbonatized and talcifized olivinite, harzburgite, wehrlite, pyroxenite of Hiep Duc Complex $\left(\sigma \mathrm{PZ} Z_{1} h d\right)$; gabbro, gabbrodiabase of Nui Ngoc Complex ( $\left.v_{\mathrm{PZ}} n n\right)$; diorite, quartz-diorite, granodiorite, tonalite 
Vietnam Journal of Earth Sciences, 39(1), 27-46

and granite of Tra Bong Complex $(\delta-\gamma \delta \mathrm{O}-\mathrm{S}$ $t b)$; medium-grained porphyritic two-mica gneissogranite of marginal facies, melanocratmelanocratic coarse- to medium-grained twomica gneissogranite of central facies, fine- to medium-grained two-mica gneissogranite, granite, pegmatite bearing big scales of mica, aplite granite of Dai Loc Complex $\left(\mathrm{\gamma aD}_{1} d l\right)$; gabbrodiorite, diorite, quartz -biotitehornblende diorite, horblende-biotite granodiorite, porphyritic hornblende granodiorite, hornblende-biotite granite, spessartite, porphyritic diorite of Ben Giang Que Son Complex ( $\left.\gamma \xi \mathrm{PZ}_{3} b g-q s\right)$; gabbro, melanocratic coarse- to medium-grained gabbropyroxenite of Cha Val Complex (vaT $c v)$; biotite granite, two-mica granite, granite aplite, tourmaline- and garnet-bearing pegmatite of Hai Van Complex $\left(\mathrm{\gamma aT}_{3} h v\right)$; biotite granite, leucocratic medium- to coarsegrained quartz-rich two-mica granite, twomica granite, fine-grained leucocratic quartzrich alaskite granite of $\mathrm{Ba} \mathrm{Na}$ Complex $(\gamma \mathrm{K}-\mathrm{E}$ $b n)$.

Within a radius of $30 \mathrm{~km}$ from the center of the main dam of Song Tranh 2 hydropower plant, tectonic faults are developed in different directions, including sub-parallel, northwest - southeast and northeast southwest fault systems. The main faults include first order Tam Ky - Phuoc Son fault; of second order is Hung Nhuong - Ta Vy fault; and third order is Tra Bong fault; and of fourth order includes Suoi Nha Nga, Song Gia, Song Nuoc Trang, Song Nuoc Xa faults and higher order faults (Figure 3)

\subsection{Planned sites of nuclear power plants Ninh Thuan 1\&2}

Areas planned to build nuclear power plants Ninh Thuan $1 \& 2$ are located in the Thuan Nam and Vinh Hai districts (Ninh Thuan province) (Figure 1).
This region is located in Late Mesozoic Da Lat active continental margin (Tran Van Tri, $\mathrm{Vu}$ Khuc et al., 2009). The study area is composed mostly of granitoids of Dinh Quan, Deo $\mathrm{Ca}$ and $\mathrm{Ca} \mathrm{Na}$ complexes, in wich the granitoids of the Deo $\mathrm{Ca}$ and Dinh Quan complexes occupied most of the area (Figure 4). The Late Jurassic Dinh Quan complex $\left(\gamma \mathrm{J}_{3}\right.$ $đ q)$ is composed of granodiorite, diorite, fineto medium grained quartz diorite. The Cretaceous Deo Ca complex $(\gamma \mathrm{K} d c)$ is comprised of biotite granodiorite, fine- to medium -grained quartz monzodiorite granite, medium- to coarse-grained, sometime porphyritic biotite (hornblend) granosyenite, fine-grained granite and dykes of porphyritic granite, granosyenit, aplite and pegmaite. The Late Creaseous $\mathrm{Ca} \mathrm{Na}$ complex $\left(\gamma \mathrm{K}_{2} c n\right)$ has small distributive area and is consisted of biotite-muscovite granite, alaskite and dykes of porphyritic granite, aplite and pegmatite. Also, present are a series of dykes consisting of porphyritic granite, granosyenite of Neogene Phan Rang complex ( $y \mathrm{E} p r$ ). Notably, the mentioned granitoids are penetrated by series of dykes of diabase, gabbrodiabase, gabbrodiorite of $\mathrm{Cu}$ Mong complex $(n \mathrm{E} \mathrm{cm})$. Interspersedly there are terrigenous sediments of sandstone, sandy siltstone, shale, horns rocks of $\mathrm{La} \mathrm{Nga}$ formation $\left(\mathrm{J}_{2} \ln \right)$, intermediate volcanic, subvolcanic rocks of Deo Bao Loc formation $\left(\mathrm{J}_{3}\right.$ $d b l$ ), acidic eruptive rocks of Nha Trang ( $\mathrm{K}$ $n t)$ and Don Duong $\left(\mathrm{K}_{2} \quad d d\right)$ formations (Figure 4). Neogene sediments of Maviek formation $\left(\mathrm{N}_{2}{ }^{2} m v\right)$ include lime gritstone and sandstone. The Middle Pleistocene sediments of Phan Thiet formation $\left(\mathrm{Q}_{1}{ }^{2} p t\right)$ are mainly red, yellowish brown fine quartz sand. The middle - upper Pleistocene sediments consist of sand, pebbles, gravel, grit, silt and clay and Holocene sediments are sand, silt and clay (Figure 4). 


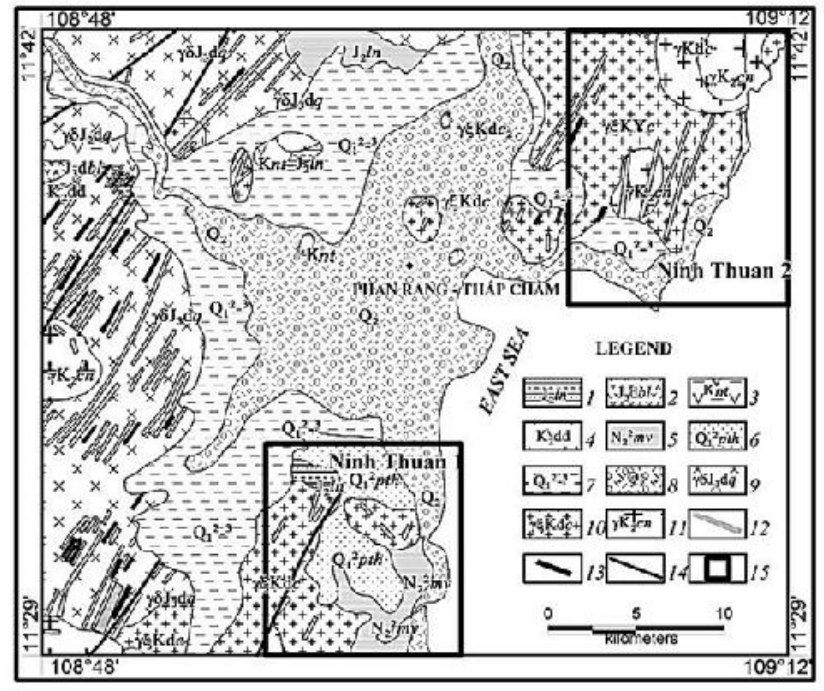

$\leftarrow$ Figure 4. Geologiacal map of Ninh Thuan $1 \& 2$ area and adjacent (modified from Geological and Mineral Resources Map of Vietnam on 1:200,000, 2005)

1. La Nga formation $\left(\mathrm{J}_{2} \ln \right) ; 2$. Deo Bao Loc formation $\left(\mathrm{J}_{3} d b l\right) ; 3$. Nha Trang formation $(\mathrm{K} n t)$; 4. Don Duong formation $\left(\mathrm{K}_{2} d d\right)$; 5. Maviek formation $\left(\mathrm{N}_{2}^{2} m v\right)$; 6. Phan Thiet formation $\left(\mathrm{Q}_{1}^{2} p t\right)$; 7. Midle - Upper Pleistocene sediments; 8. Holocene sediments; 9. Dinh Quan complex $\left(\gamma \mathrm{J}_{3} d q\right)$ : Diorite, granodiorite; 10. Deo Ca complex $(\gamma \mathrm{K} d c)$ : Granodiorite,granite; 11. $\mathrm{Ca} \mathrm{Na}$ complex $\left(\gamma \mathrm{K}_{2} c n\right)$ : Granite, alaskite; 12. Porphyric granite Dykes of Rang complex ( $y \mathrm{pE} p r) ; 13$. Diabas, gabbrodiabas dykes of $\mathrm{Cu}$ Mong complex $($ rp $\mathrm{E} \mathrm{cm})$

According to the geological map of 1: 200,000 scale (Nha Trang and Dalat sheets) the study area has a number of northeast southwest faults. But the latest research results reported by $\mathrm{Vu}$ Van Chinh in the framework of a national project "Study and evaluation of active faults serving the site selection to build nuclear power plants in Ninh Thuan province", code 01/2012, show that only 03 small faults had been detected in neighborhood of expected site of nuclear power plants Ninh Thuan 2, named Nui Ba Duong, VL109-110 and VL111 faults (see Figure 9). In the neighborhood of Ninh Thuan 1 site have been revealed fracture zones Suoi Mia, Suoi Bau Ngu, Suoi Mot, Bau Ngu - Son Hai, Van Lam - Tu Thien, Vinh Truong (see Figure 10), and in the neighborhood of Ninh Thuan 2 site have been detected East Hon Gio, Nui Ong Kinh, Da Hang, VL111, VL110, Deo Dinh Ba, VL241, VL100 and Mui Thi fracture zones (Figure 11).

\section{Method of measuring Rn concentration in soil gas}

Concentrations of $\mathrm{Rn}$ in soil gas were measured along profiles, which were identified in collaboration with geologists to their crossing the fault lines or fracture zones. However, the setting of profiles also depends on field conditions (relief, water bodies, river and stream set, characteristics of ground and rocks, etc...), so the most of the profiles are not a straight line. Distances between measuring points in a profile were chosen in the range of 25 to $30 \mathrm{~m}$. The distance was determined based on migration ability of $\mathrm{Rn}$ in soil gas (Barnet et al., 2008). The positions of measuring points were located by a Garmin GPSmap 60CSx GPS.

$\mathrm{Rn}$ concentrations in soil gas were measured using solid-state nuclear track detectors (SSNTDs). This method shows many advantages compared to Alpha scintillation detectors (Nguyen Van Pho, 1996). Film-detectors DOSIRAD LR115 (type 2P, serial number 5058180) were used. The film-detectors were glued to the bottom of the plastic cups, which then had been covered with $\mathrm{PE}$ film to prevent direct penetration of water. At each measuring point, the plastic cup containing film-detector was placed face-down in the bottom of the drag pit 
of $25 \mathrm{~cm}$ diameter and 40-50 $\mathrm{cm}$ deep (Figure $5)$. The average measuring time was 5 days, and the time of placing and collecting of detectors was carefully recorded with accuracy in a minute. Collected film-detectors were carefully preserved in plastic bags for further treatment. At each setpoint of the detector, the pit bottom radiation intensity was measured using radiometer RP 88 (Russia) to eliminate the anomalies caused by the accumulation of radioactive elements. Etching, track counting and radon concentration calculating were completed at the Institute for Nuclear Science and Technology (Hanoi).

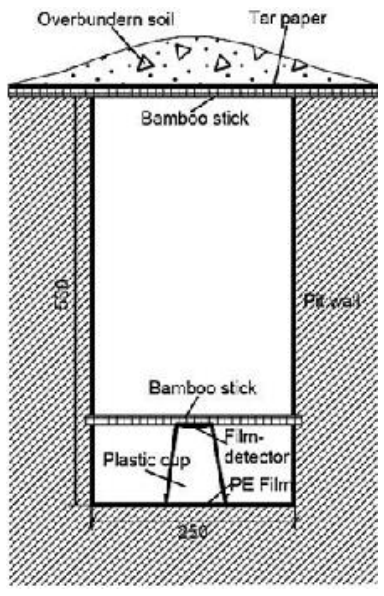

Figure 5. Setting of detector in the pit

Data were analyzed by the statistical method, ranges of background values, thresholds and anomalies were determined using boxplot method (Reimann et al., 2005).

\section{Results of soil radon gas measurement}

\subsection{Thac Ba area}

Measured profiles were focused in the southeastern area of the lake, where the main dams are located, including dam N.9 in the south and main dam and hydropower plant in the southeast. Two profiles were performed in the dam N.9 area and 9 remaining profiles were in the east of the main dam and around the hydropower plant (Figure 6).

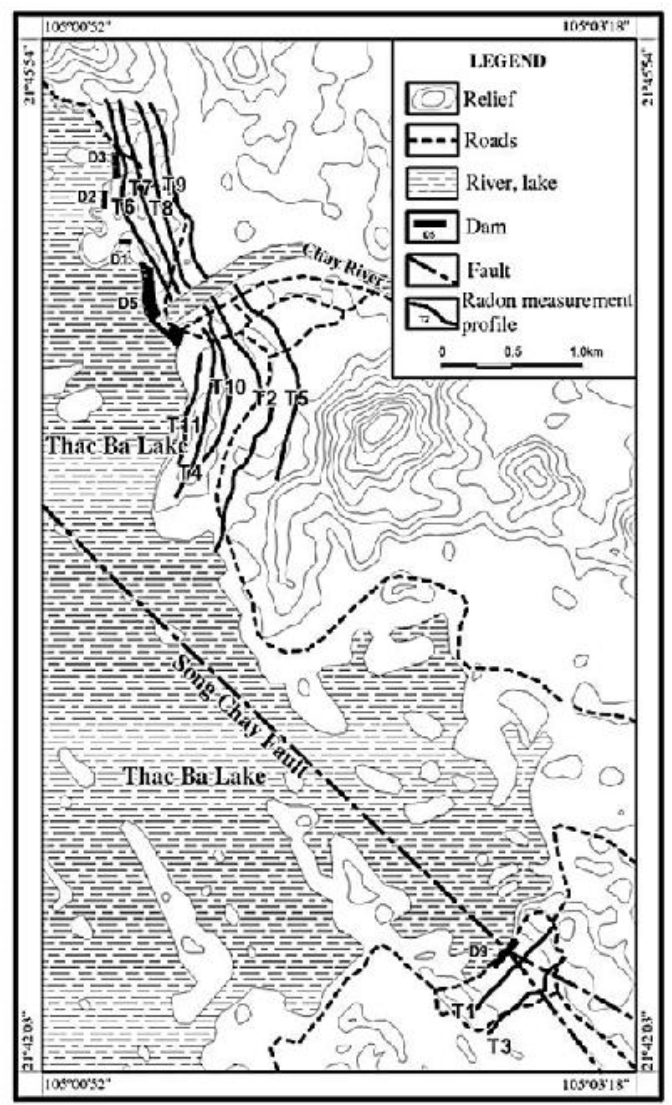

Figure 6. Distribution of radon measurement profiles in Thac Ba area

Total 452 data points were obtained. The results showed that concentrations of $\mathrm{Rn}$ in soil gas varied from $72 \mathrm{~Bq} / \mathrm{m}^{3}$ to 273.133 $\mathrm{Bq} / \mathrm{m}^{3}$, mean $=12.840 \mathrm{~Bq} / \mathrm{m}^{3}$. The statistical parameters are shown in Table 1. Boxplot diagram suggests the background range from 72 $\mathrm{Bq} / \mathrm{m}^{3}$ to $28.139 \mathrm{~Bq} / \mathrm{m}^{3}$, and the threshold value is $28.139 \mathrm{~Bq} / \mathrm{m}^{3}$ (Figure 7). So 46 of total 452 measured points have anomalous concentrations, and highest anomaly value reached $273.133 \mathrm{~Bq} / \mathrm{m}^{3}$. 
Pham Tich Xuan, et al./Vietnam Journal of Earth Sciences 39 (2017)

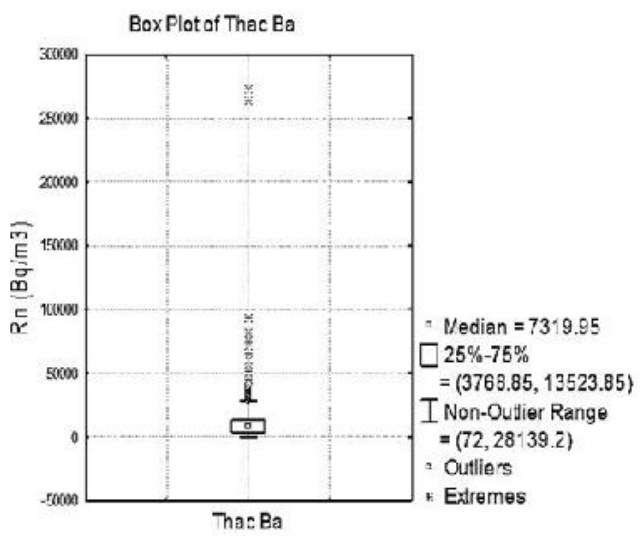

$\leftarrow$ Figure 7. Boxplot diagram of radon concentration in Thac Ba area

\subsection{Song Tranh 2 area}

In the hydropower plant Song Tranh 2 and adjacent area, radon measurements were performed along 25 profiles with 782 data points obtained. Distribution of profiles is shown in Figure 8.

The concentrations of radon varied from $29 \mathrm{~Bq} / \mathrm{m}^{3}$ to $77.729 \mathrm{~Bq} / \mathrm{m}^{3}$, mean $\bar{x}=2225$ $\mathrm{Bq} / \mathrm{m}^{3}$. The statistical parameters are shown in Table 1.

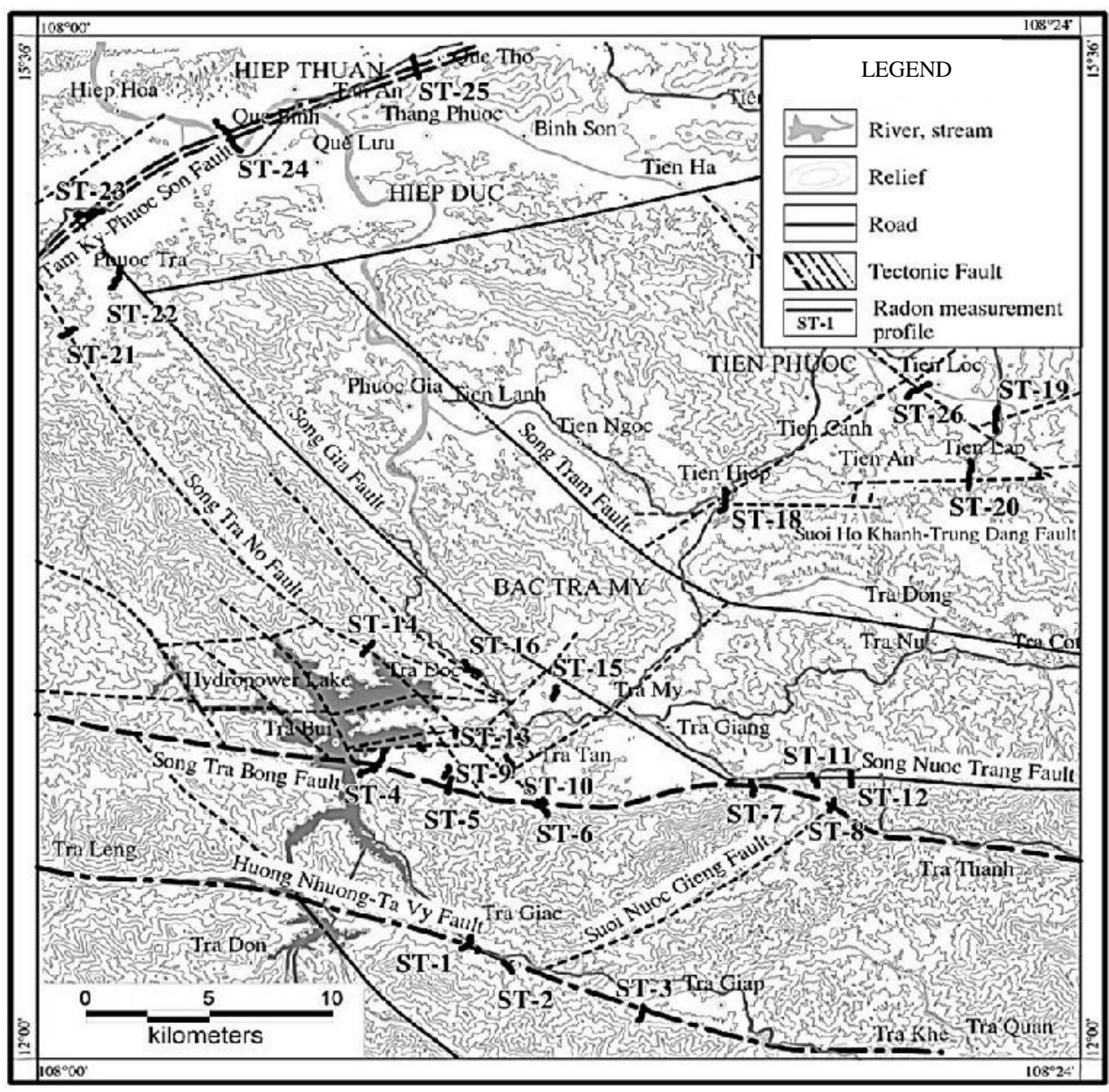

Figure 8. Distribution of radon measurement profiles in Song Tranh 2 hydropower plant and adjacent 
Vietnam Journal of Earth Sciences, 39(1), 27-46

Table 1. Radon concentrations in Thac Ba, Ninh Thuan andSongTranh2areas

\begin{tabular}{|c|c|c|c|c|c|}
\hline \multirow{2}{*}{ Site } & \multirow{2}{*}{ (n) } & \multicolumn{3}{|c|}{ Concentrations $\left(\mathrm{Bq} / \mathrm{m}^{3}\right)$} & \multirow{2}{*}{ SD } \\
\hline & & $\operatorname{Mean}(x \overline{)}$ & in & Max & \\
\hline Thac Ba & 452 & 12.840 & 72 & 27.3133 & 21.750 \\
\hline Ninh Thuan & 880 & 5.515 & 6 & 52.627 & 5.980 \\
\hline Song Tranh 2 & 780 & 2.225 & 29 & 77.729 & 4.871 \\
\hline
\end{tabular}

Boxplot diagram shows the background range from $29 \mathrm{~Bq} / \mathrm{m}^{3}$ to $3.855 \mathrm{~Bq} / \mathrm{m}^{3}$, the threshold value is $3.855 \mathrm{~Bq} / \mathrm{m}^{3}$ (Figure 9). Thus, there are 116 points having anomaly concentrations of radon from total 782 measured points, including the highest value of $77.729 \mathrm{~Bq} / \mathrm{m}^{3}$.

\subsection{Ninh Thuan area}

In the area of Ninh Thuan 1, radon measurements were carried out along 11 profiles with 401 data points (Figure 10); while in the area of Ninh Thuan $2 \mathrm{Rn}$ measurements were conducted along 15 profiles with 479 data points (Figure 11)

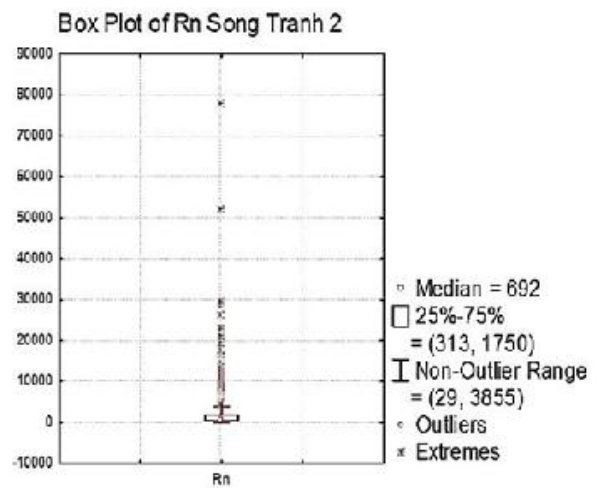

Figure 9. Boxplot diagram of radon concentrations in Song Tranh 2 area and adjacent

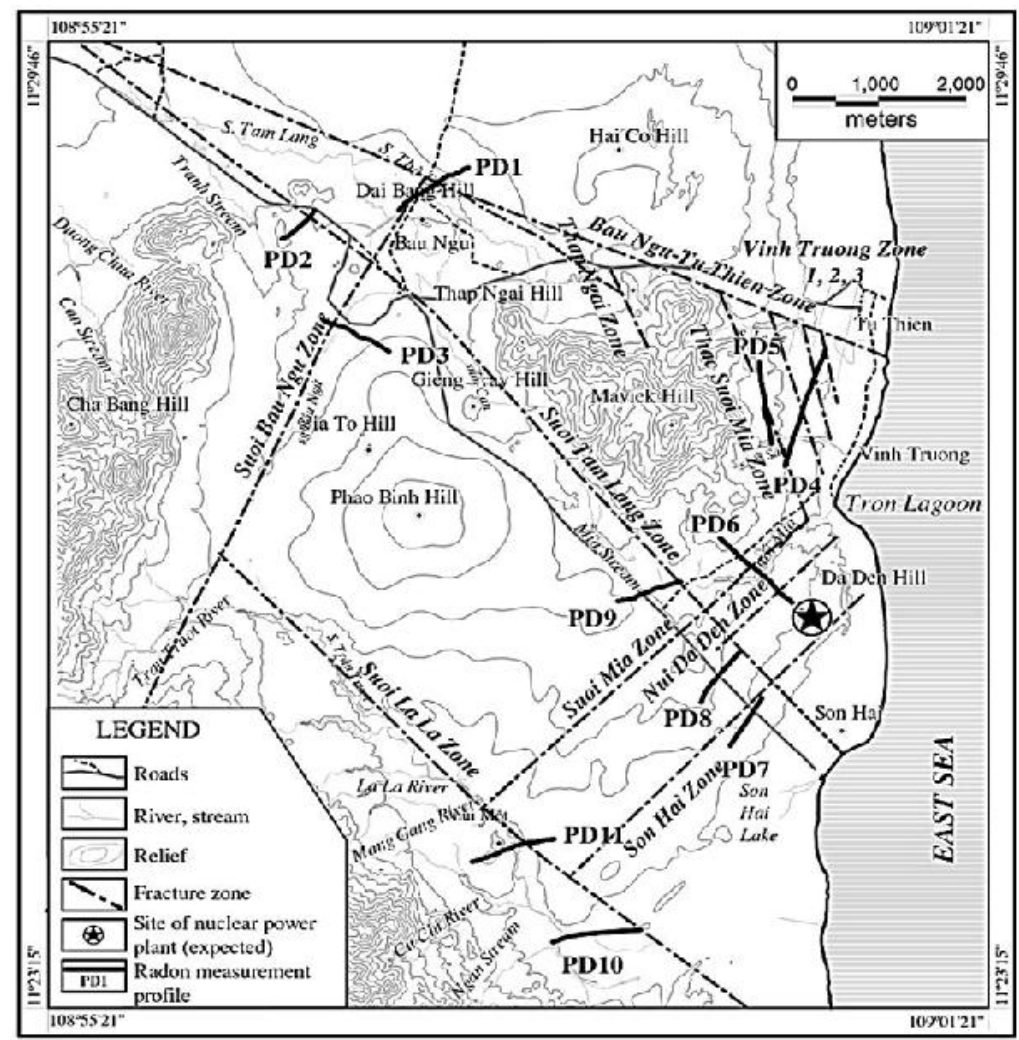

Figure 10. Distribution of radon measurement profiles in Ninh Thuan 1 area 
Pham Tich Xuan, et al./Vietnam Journal of Earth Sciences 39 (2017)

The results showed that concentrations of radon varied from $6 \mathrm{~Bq} / \mathrm{m}^{3}$ to $52.627 \mathrm{~Bq} / \mathrm{m}^{3}$, and mean $=5515 \mathrm{~Bq} / \mathrm{m}^{3}$. The statistical parameters are shown in Table 1. Boxplot diagram showed that the background concentrations fall in range $6 \mathrm{~Bq} / \mathrm{m}^{3}$ to $15.410 \mathrm{~Bq} / \mathrm{m}^{3}$, the threshold value is $15.410 \mathrm{~Bq} / \mathrm{m}^{3}$ (Figure 12). So 58 of total 880 measured points have anomalous concentrations, and highest anomaly value reached $52.627 \mathrm{~Bq} / \mathrm{m}^{3}$.
Notably, the results of radon measurements showed the difference in radon concentrations in the Ninh Thuan 1 and Ninh Thuan 2 areas. Generally, Ninh Thuan 2 area had higher concentrations of radon compared with Ninh Thuan 1. While in the Ninh Thuan 1 area the maximum value of radon concentrations was just only $16.513 \mathrm{~Bq} / \mathrm{m}^{3}$ and slightly exceeded the threshold, in the Ninh Thuan 2 area the maximum value of radon concentrations reached $52.627 \mathrm{~Bq} / \mathrm{m}^{3}$.

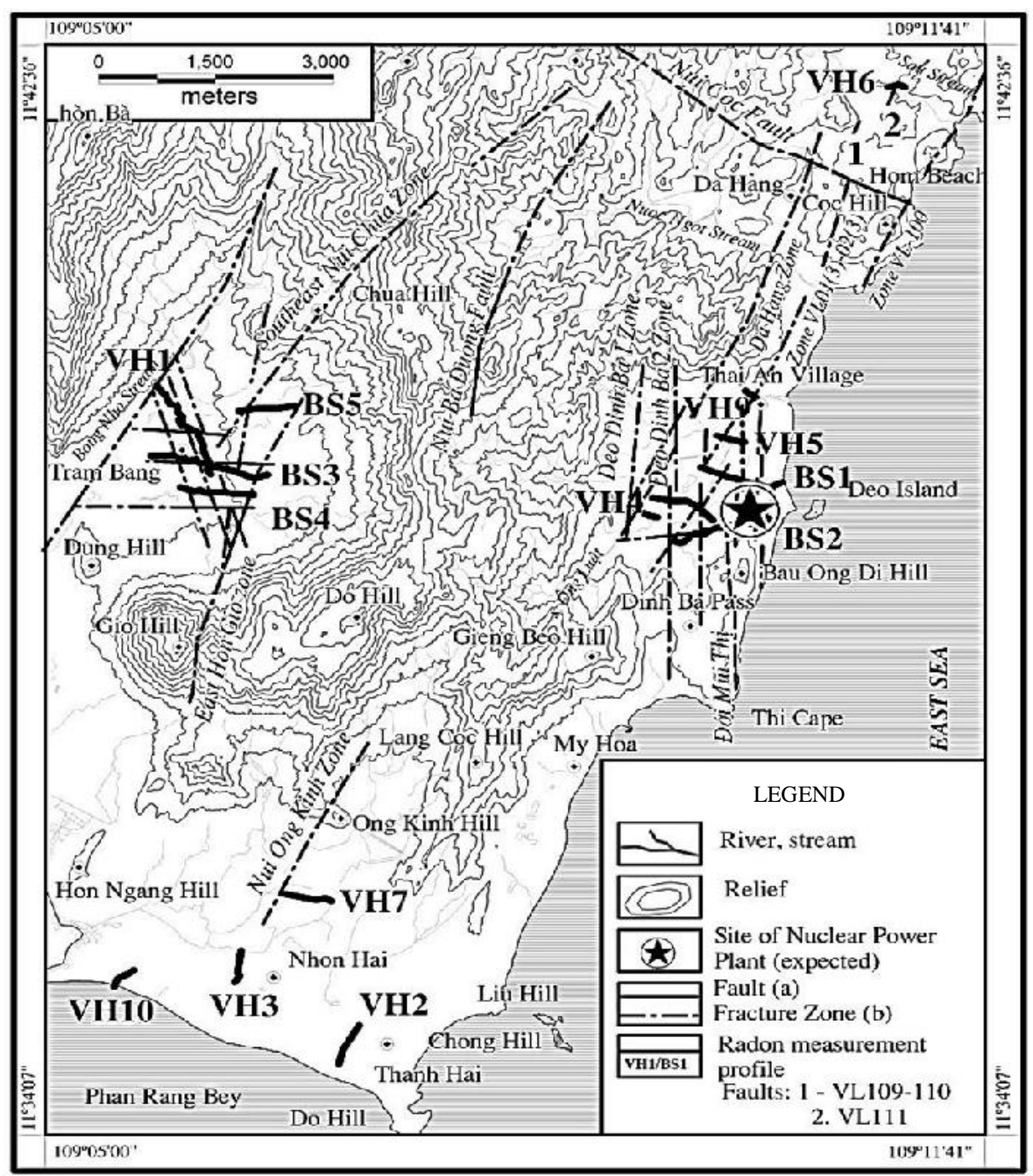

Figure 11. Distribution of radon measurement profiles in Ninh Thuan 2 area 
Vietnam Journal of Earth Sciences, 39(1), 27-46

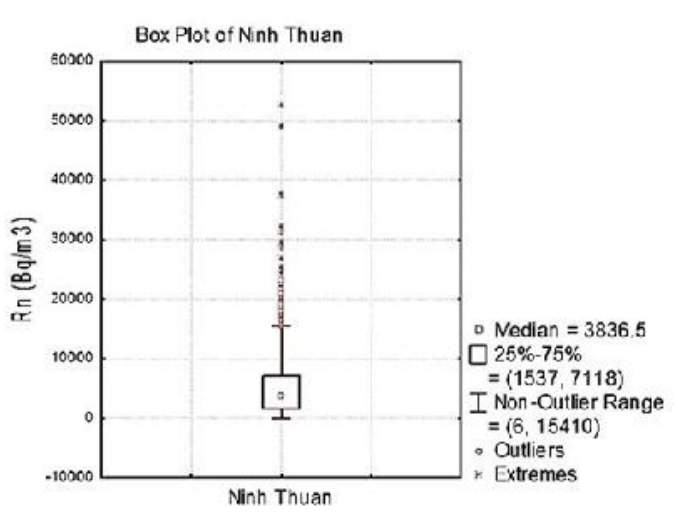

Figure 12. Boxplot diagram of radon concentrations in Ninh Thuan area

\section{Discussion}

\subsection{Relationship between radon concentration and fault activity}

The concentration of radon in soil gas depends on many factors, but mostly on geological features, lithologies and tectonic activities in a given region. Therefore, the absolute value of radon in soil gas in different regions can be very different. For this reason, a soil radon gas mapping may have various different classifications of radon concentrations. In Germany, Kemski et al. (2001) divided radon concentrations into 4 categories such as: a) low $\left(<10 \mathrm{kBq} / \mathrm{m}^{3}\right) ;$ b) medium $\left(10-100 \mathrm{kBq} / \mathrm{m}^{3}\right.$; c) increased $\left(100-500 \mathrm{kB} / \mathrm{m}^{3}\right)$ and d) high $\left(>500 \mathrm{kBq} / \mathrm{m}^{3}\right)$. While in Hong Kong used is 3 category scale as follows a) low $(<10$ $\left.\mathrm{kBq} / \mathrm{m}^{3}\right)$; b) medium $\left(10-100 \mathrm{kBq} / \mathrm{m}^{3}\right)$ and c) high $\left(>100 \mathrm{kBq} / \mathrm{m}^{3}\right)$ (Tung et al., 2013). Classifications of concentration levels using absolute values of concentration mentioned above were based on criteria for human health and ecological environment safety and only had implication in soil radon gas mapping with environmental protection purpose.

Many studies (King et al., 1996; Moussa and Arabi, 2003; Ciotoli et al., 1999, 2007) have shown that the radon anomalous concentrations are sensitive to fault activity. The value of anomalous radon concentrations can many times, even dozens of times higher than background depending on the activity level of a fault (AI-Tamimi and Abumurad, 2001; Wang et al., 2014, Seminsky et al., 2013). The maximum radon concentrations and background values in some faults are shown in Table 2 (Richon et al., 2010), suggesting that maximum concentrations and background levels are very different for different faults, but in general, the maximum values are many folds greater than background values (high ratio of $\mathrm{Max} / \mathrm{BG}$ ).

Table 2. Maximum concentration and mean background level of radon in soil gas at some faults (Richon et al., 2010)

\begin{tabular}{|c|c|c|c|c|}
\hline Location & Fault & $\operatorname{Max} \operatorname{Rn}\left(B q / m^{3}\right)$ & $\begin{array}{l}\text { Mean background } \\
\text { level }\left(\mathrm{Bq} / \mathrm{m}^{3}\right)\end{array}$ & Ratio of Max/BG \\
\hline Calaveras Fault, Hollister, California & Strike-Slip & 30000 & 3000 & 10 \\
\hline San Andreas Fault, Point Reyes, California & Strike-Slip & 30000 & 5000 & 6 \\
\hline Johnson Valley Fault, California & Strike-Slip & 4000 & 400 & 10 \\
\hline Dead Sea, Israel & Normal & $>500000$ & 26000 & $>19$ \\
\hline Dead Sea Transform, Wadi Araba, Jordan & Strike-Slip & 1800 & 1000 & 1.8 \\
\hline Dead Sea Transform, Jordan & Strike-Slip & 3000 & $<1000$ & $>3$ \\
\hline North Anatolian Fault, Turkey & Strike-Slip & 9800 & 6000 & 2 \\
\hline Shan-Chiao Fault, Taiwan & Normal & 28000 & 6000 & 5 \\
\hline Crati graben, Italy & Normal & 39000 & 9100 & 4 \\
\hline Norht and Northwestern Greece & Normal & 13000 & 2000 & 6.5 \\
\hline Jaut Pass, Pyrenees, France & Normal & 70000 & 10000 & 7 \\
\hline Bad Nauheim Fault, Aachen, Germany & Normal & $>1000000$ & 30000 & $>33$ \\
\hline Neuwied Basin, Rhine Graben, Germany & Normal & 140000 & $<10000$ & $>14$ \\
\hline Main Central Thrust, Nepal & Thrust & 60000 & 4400 & 14 \\
\hline
\end{tabular}


Pham Tich Xuan, et al./Vietnam Journal of Earth Sciences 39 (2017)

Seminsky and Demberel (2013), when studying the relationship between the concentration of radon in soil gas and activity of faults in Central Mongolia proposed to use Radon Activity Index KQ - the ratio between the highest radon concentration (Qmax) and concentration of radon outside the fault zone (Qmin) for classification of activity of radon. Accordingly, for the Middle Mongolian the faults are characterized by levels of Radon Activity Index as follows: ultra-high (KQ > 10), high $(10>\mathrm{KQ}>5)$, increased $(5>\mathrm{KQ}>3)$, medium $(3<\mathrm{KQ}>2)$ and low $(\mathrm{KQ}<2)$. However, comparing the maximum anomalies with the lowest concentration outside the fault zone will lead to more uncertainty, cite, for example, what is value outside the fault zone, what position is considered to be outside the faults zone. Hence the comparison value must be calculated based on a statistical basis, such as comparing the maximum value to the threshold or the average value of the background. Wang et al., 2014 identified anomalous concentrations and the threshold of background for a number of faults in the Tangshan area (North China). If using the method for calculating Radon Activity Index as the ratio between the maximum value and the threshold of the background can be seen the all of active faults have quite large indexes, ranging from 6.6 to 18,4 (Table 3).

Table 3. Maximum concentration and background level of radon at some faults in China (Wang et al., 2014)

\begin{tabular}{|c|c|c|c|c|c|}
\hline \multirow[b]{2}{*}{ Location } & \multicolumn{3}{|c|}{ Rn concentration $\left(\mathrm{Bq} / \mathrm{m}^{3}\right)$} & \multirow{2}{*}{$\begin{array}{ll} & \text { Standard } \\
\text { Deviation } & \text { (SD) }\end{array}$} & \multirow{2}{*}{ Ratio of Max/BG } \\
\hline & Min & Max & Backgroundvalue $(\mathrm{BG})$ & & \\
\hline \multirow[t]{2}{*}{ Tangshan Lhasa, Tibet } & 411.8 & 38470.6 & 4730.4 & 4992.6 & 8.1 \\
\hline & 757.6 & 87402.6 & 7634.9 & & 11.5 \\
\hline Yanhuai basin, Hebei & 1302.0 & 57812.0 & 8105.78 & 5937.4 & 7.1 \\
\hline Haiyuan, Ningxia & 1000.0 & 38300.0 & 5800.0 & & 6.6 \\
\hline Jixian Mountain, Tianjing & 52.0 & 58646.0 & 3188.0 & 4598.0 & 18.4 \\
\hline
\end{tabular}

Using arguments described above, we suggest using the ratio between the anomalous concentration of radon and the threshold value as index of radon activity $\left(\mathrm{K}_{\mathrm{Rn}}\right)$ and use scheme of classification provided by Seminsky and Demberel (2013) to classify radon activity under this index. So we will have 5 levels of ac- tivity of radon corresponding to the Radon activity Indexes $\mathrm{K}_{\mathrm{Rn}}$ as follows ultra-high $\left(\mathrm{K}_{\mathrm{Rn}}>\right.$ 10), high (10> $\mathrm{K}_{\mathrm{Rn}}>5$ ), increased ( $5 \geq \mathrm{K}_{\mathrm{Rn}}>$ $3)$, medium ( $\left.3 \geq K_{R n}>2\right)$ and low $\left(K_{R n} \leq 2\right)$. Corresponding to 5 levels of Radon Activity Indexes $\mathrm{K}_{\mathrm{Rn}}$, we have 5 levels of fault activity expression (Table 4).

Table 4. Classification of radon activity index and correlative activity expression of fault

\begin{tabular}{|c|c|c|}
\hline \multicolumn{2}{|c|}{ Radonactivityindex } & \multirow{2}{*}{ Expression of fault activity } \\
\hline $\mathrm{K}_{\mathrm{Rn}}$ & Level & \\
\hline $\mathrm{K}_{\mathrm{Rn}}>10$ & Ultra-high & Fault having strong activity expression \\
\hline $10 \geq \mathrm{K}_{\mathrm{Rn}}>5$ & High & Fault having clear activity expression \\
\hline $5 \geq K_{R n}>3$ & Increased & Fault having activity expression or existence of strong tectonic fracture zone \\
\hline $3 \geq K_{R n}>2$ & Medium & Fault having not clear activity expression or existence of fracture zone \\
\hline $\mathrm{K}_{\mathrm{Rn}} \underline{\mathcal{Z}}$ & Low & Fault having no activity expression or no existence of fault \\
\hline
\end{tabular}

Radon Activity Index $\mathrm{K}_{\mathrm{Rn}}$ allows identifing the existence as well as the activity expression of tectonic faults, although its activity rates need further studies.

\subsection{Fault activities in the Thac Ba area}

The concentrations of soil radon gas measurements show 46 out of 425 data points are anomalous. The anomalous points mainly distribute in the main dam and hydropower plant area with 43 points having radon concentrations ranging from $28.139 \mathrm{~Bq} / \mathrm{m}^{3}$ to 273.133 $\mathrm{Bq} / \mathrm{m}^{3}$. In the dam N.9 area there are only 03 of total 81 data points having anomalous concentrations ranging from $28.481 \mathrm{~Bq} / \mathrm{m}^{3}$ to 35.988 $\mathrm{Bq} / \mathrm{m}^{3}$. Radon Activity Index $\mathrm{K}_{\mathrm{Rn}}$ var- 
ied from 1 to 9.75, including TB2-22 and TB2-49 points (Profile N.2) having high $\mathrm{K}_{\mathrm{Rn}}$. Anomalous radon concentrations and high Radon Activity Index indicated fault activities in this area. Notably, anomalous points are distributed in the sub-meridian direction coinciding with the direction of the regional extension structure and reflecting strike-slip tectonic stress field with sub-meridian compression in recent time (Figure 13). This observation is consistent with the Chay River fault reported elsewhere (Nguyen Trong Yem, 1996, Nguyen Dang Tuc, 2000). In summary, the results of soil radon gas measurements recorded the activity of Chay River fault and neighboring areas suggest the right strike-slip mechanism at the present time.

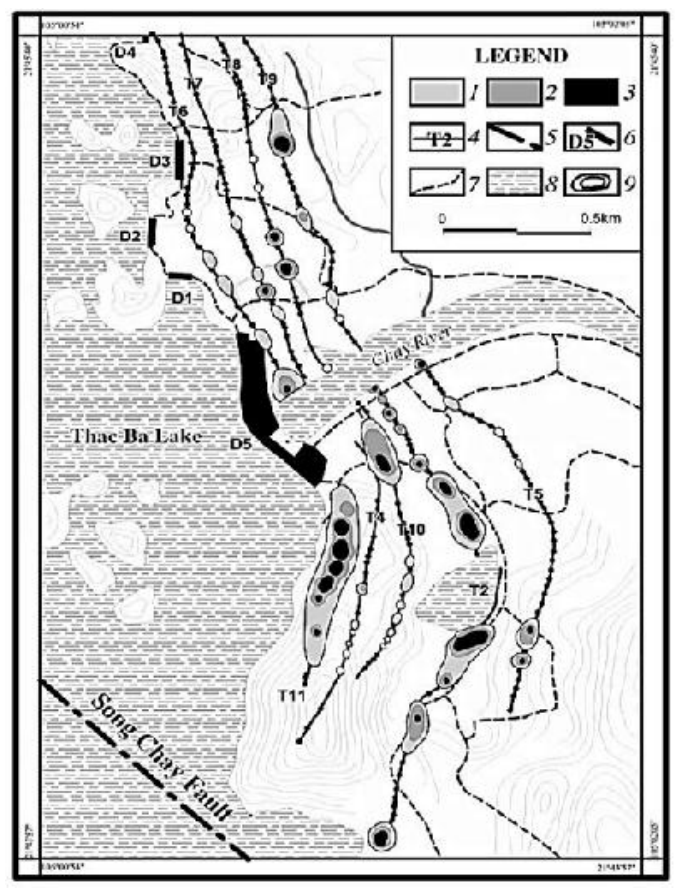

Figure 13. Map showing sub-meridian distribution of radon anomalies in Thac Ba ares: 1 - 3: Radon concentrations: 1 - 10,000-20,000 Bq/m $\mathrm{m}^{3}, 2-20,000-30,000 \mathrm{~Bq} / \mathrm{m}^{3}$,

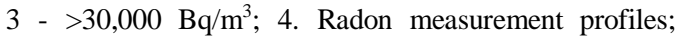
5. Fault; 6. Dam; 7. Roads; 8. Lake; 9. Relief

\subsection{Fault activities in the Song Tranh 2 area}

In the Song Tranh 2 hydropower plant and adjacent area, 114 out of 782 measurements were identified as anomalous with $\mathrm{K}_{\mathrm{Rn}}$ ranging from 1.00 to 20.16, including 23 points having KRn at increased or higher levels.

In the northwest - southeast segment of Hung Nhuong - Ta Vy fault, soil radon gas was measured in 3 profiles. In a total of 98 measurements, 19 were recognized as anomalous, with 3 points having KRn at a high level and 3 others at increased level. Notably, in both profiles ST-1 and ST-3 the anomalies with high $\mathrm{KRn}$ had been occurred, including ST101 and ST102 points in profile ST-1 with $\mathrm{K}_{\mathrm{Rn}}=5.94$ and 7.67 respectively, point ST317 in profile ST-3 with $\mathrm{K}_{\mathrm{Rn}}=7.44$ (Figure 14). In profile ST-2 there are 2 anomalous points with $\mathrm{K}_{\mathrm{Rn}}=1.07$ and 2.3 (medium and low levels), but these points are quite far from fault. Thus, the existence of anomalies with radon activity index at the high level indicates that Hung Nhuong - Ta Vy fault shows clear activity expression in recent time at least in the northwest - southeast segment.

In the Tra Bong fault area measurements had been carried out in 4 profiles (St-4, ST-6, ST-7 and ST-8), and 23 of total 136 measured points show anomalous radon concentrations, including 2 points having $\mathrm{KRn}$ at increased level and 01 point (ST613, profile ST-6) having highest radon concentration (77727 $\left.\mathrm{Bq} / \mathrm{m}^{3}\right)$ with $\mathrm{KRn}$ at ultra-high level $\left(\mathrm{K}_{\mathrm{Rn}}=\right.$ 20.16). The presence of anomalies with $\mathrm{KRn}$ at increased or higher levels may be the evidence of activity of Tra Bong fault in recent time. However, it should be added that most of the anomalous points with $\mathrm{K}_{\mathrm{Rn}}$ at increased or higher level are located at intersections of Tra Bong with northwest - southeast faults. For example, point ST613 with $\mathrm{K}_{\mathrm{Rn}}=20.16$ is located at the intersection with Song Tra No fault, point ST722 (profile ST-7) - at the intersection with Song Gia fault, or the anomalies in the profile ST-4 also (Figure 15), while in profile ST-8 outside the junctions of this type only encountered anomalies with $\mathrm{K}_{\mathrm{Rn}}$ at medium level. Therefore, high radon activity index $K_{R n}$ at the fault intersections may be evi- 
Pham Tich Xuan, et al./Vietnam Journal of Earth Sciences 39 (2017)

denced not only by the activity of Tra Bong fault but also for northwest - southeast faults. Although in the place where profile ST-14 crossed Song Tra No fault was recognized an anomaly, but $\mathrm{K}_{\mathrm{Rn}}=2.61$ is only at the medium level, but due to execution conditions of pro- file ST-14 were very bad, so the results may not fully reflect characteristics of radon concentrations here. Nevertheless, combining with measurement results in profile ST-6 described above it can be considered that Song Tra No fault also may be active.

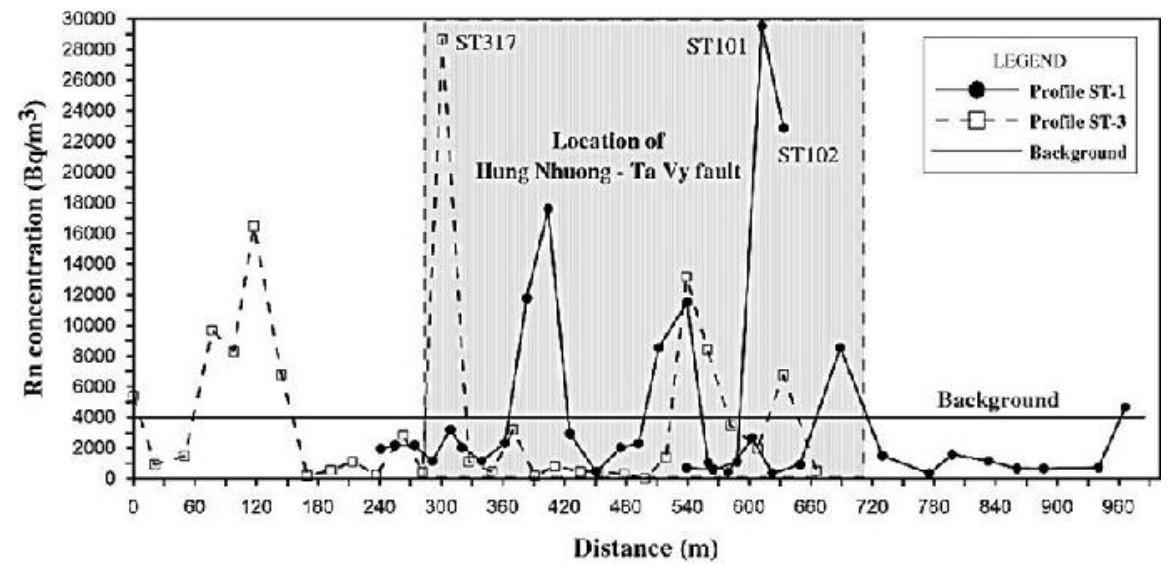

Figure 14. Combined graphic of radon concentrations at Hung Nhuong - Ta Vy fault

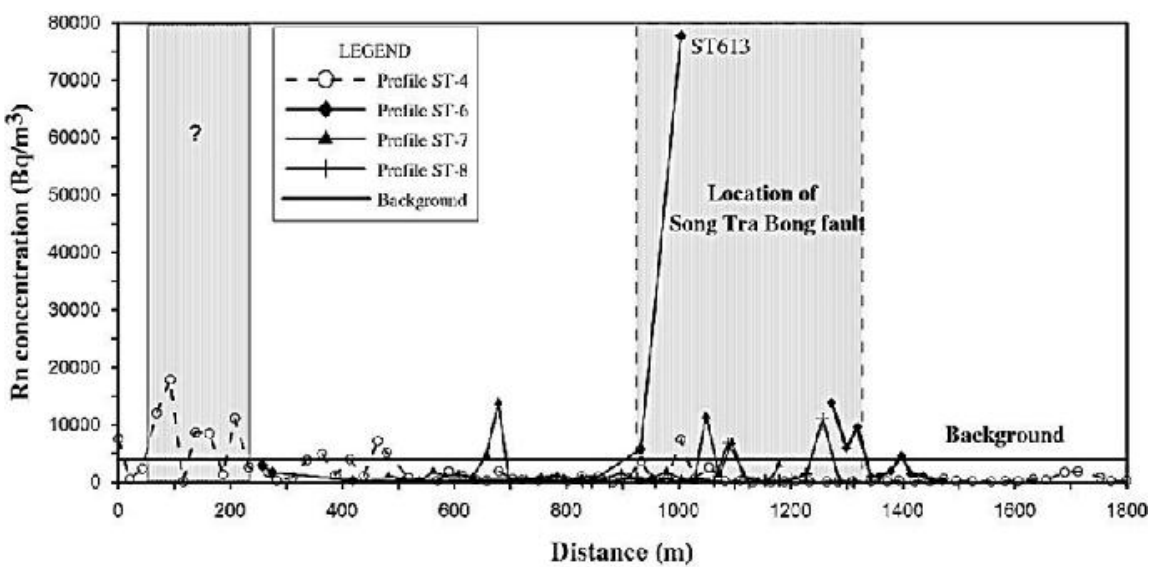

Figure 15. Combined graphic of radon concentrations at Song Tra Bong fault

In the segment of Tam Ky - Phuoc Son, that crosses study area and has northeast southwest direction, were reported 23 anomalies of total 123 measured points. However most of these anomalous points have KRn at medium or low levels, only 3 points have slightly increased $K_{R n}\left(K_{R n}\right.$ varied from 3.1 to
3.5 near the threshold value) (Figure 16). It is noteworthy that anomalous points in this fault are concentrated in its junctions with high order faults. So, according to the results of radon measurement Tam Ky - Phuoc Son fault have activity expression but not really clear in recent time. 
Vietnam Journal of Earth Sciences, 39(1), 27-46

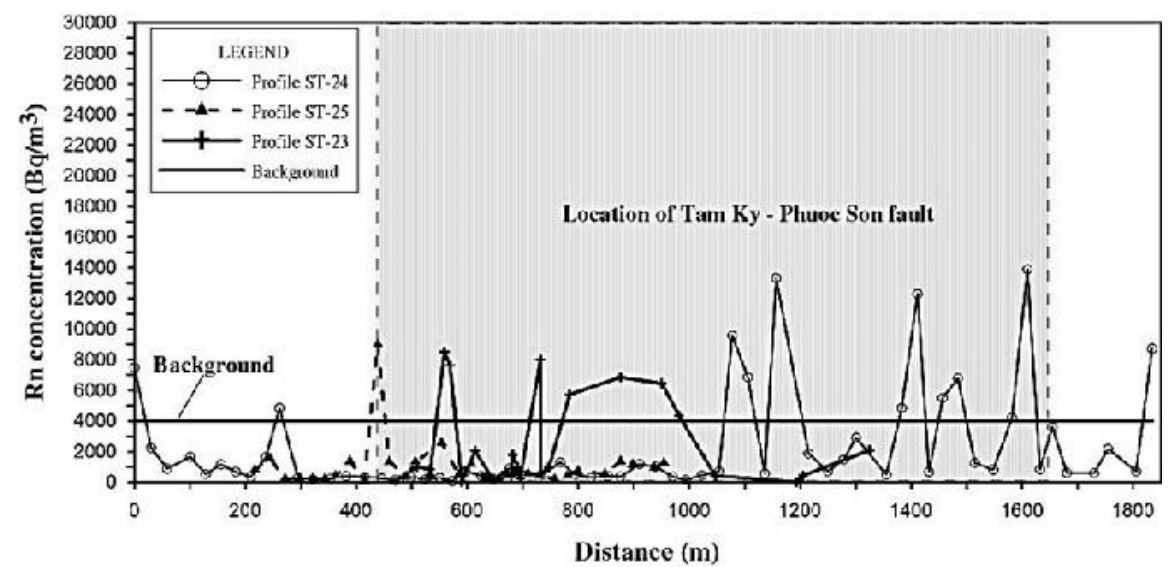

Figure 16. Combined graphic of radon concentrations at Tam Ky - Phuoc Son fault

In some sub-parallel high order faults, there observed anomalies with $\mathrm{K}_{\mathrm{Rn}}$ at high and increased levels. In the Song Nuoc Trang fault, in the profile ST-11 and ST-12 were recognized anomalous points with $\mathrm{K}_{\mathrm{Rn}}$ at increased level, proving activity expression of the fault (Figure 17). In Ho Khanh - Trung Dang fault, the point ST2037 (profile ST-20) lied directly in the fault line has anomalous radon concentration with $\mathrm{K}_{\mathrm{Rn}}=13.52$ at ultra-high level and in addition, in adjacent of this point there are some anomalies with KRn at high level, so the Ho Khanh - Trung Dang fault had clear expression of activity in recent time.

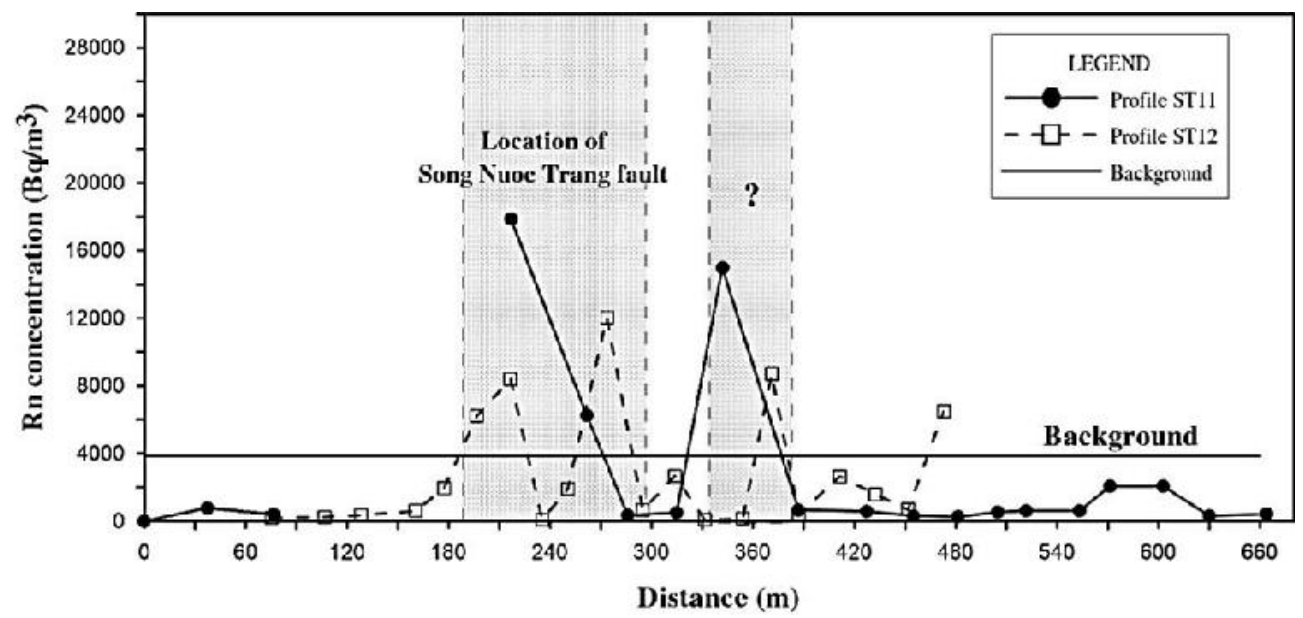

Figure 17. Combined graphic of radon concentration at Song Nuoc Trang faul

On the profile ST-18 that crossed northeast - southwest fault Suoi Deo Luu had met some anomalies, but indexes $K_{R n}$ are only at medium or low levels, except one point having $K_{R n}$ at increased level but very slightly $\left(\mathrm{K}_{\mathrm{Rn}}=\right.$
3.08), so activity expression of this fault is not clear. In the profile ST-19 crossed another northeast - southwest fault Phu Ninh also had been recognized anomalies with KRn at medium to increased levels, but the points in the 
fault line did not discover any anomalous concentration of radon, so it is difficult to conclude about it activeness.

\subsection{Fault activities in the Ninh Thuan area}

In the Ninh Thuan area, there are 63 anomalous out of total 880 measured points. Most of the anomalous points concentrated in the Ninh Thuan 2 area (62 points), while in the Ninh Thuan 1 area there was only one anomalous point. However, most of the anomanlous points have low radon activity indexes $\left(\mathrm{K}_{\mathrm{Rn}}<3\right)$, only 2 points $\mathrm{VH} 1-42$ (profile VH1) and VH4-9 (profile VH4) in Vinh Hai have $\mathrm{K}_{\mathrm{Rn}}=3.42$ and 3.18, respectively, and at increased level. Thus, in the Ninh Thuan $1 \& 2$ areas, expressions of activity of faults are not clear, even there are not expressions of activity of faults. Radon anomalies indicate the presence of fracture zones (increasing emanation) rather than expressions of active faults. The existence of tectonic fracture zone through the increase of radon concentrations was recognized in many profiles. In Ninh Thuan 1 and in Tam Lang fracture zone, although all measured radon concentrations fall within the range of background values, but in the profiles PD7, PD8, PD9 had been recognized some points with increased radon concentrations (Figure 18). In the Ninh Thuan 2 area, many points in the profiles performed in Thai An and Tram Bang showed high concentrations of radon suggesting the existence of series of fracture zones (Figure 19, 20). Comparison of radon activity indexes $\mathrm{KRn}$ obtained for the above areas shows that $\mathrm{KRn}$ indexes are different in the Thac $\mathrm{Ba}$, Song Tranh 2 and Ninh Thuan areas, where the $\mathrm{K}_{\mathrm{Rn}}$ in the Song Tranh 2 reached ultra-high level $\left(K_{R n}=20.16\right)$, high level $\left(K_{R n}=9.75\right)$ was recorded in the $\mathrm{Thac} \mathrm{Ba}$ area, whereas Ninh Thuan 1 and 2 areas show medium or low levels, except for only 2 values reached increased level $\left(\mathrm{K}_{\mathrm{Rn}} \max =3.42\right)$ (Figure 21). The difference of active radon indexes in observed areas reflects the different levels of fault activity expression in this area, in which in Thac Ba and Song Tranh 2 the activity expression of faults is clear, while in Ninh Thuan area activity expression is not clear, even no activity expression.

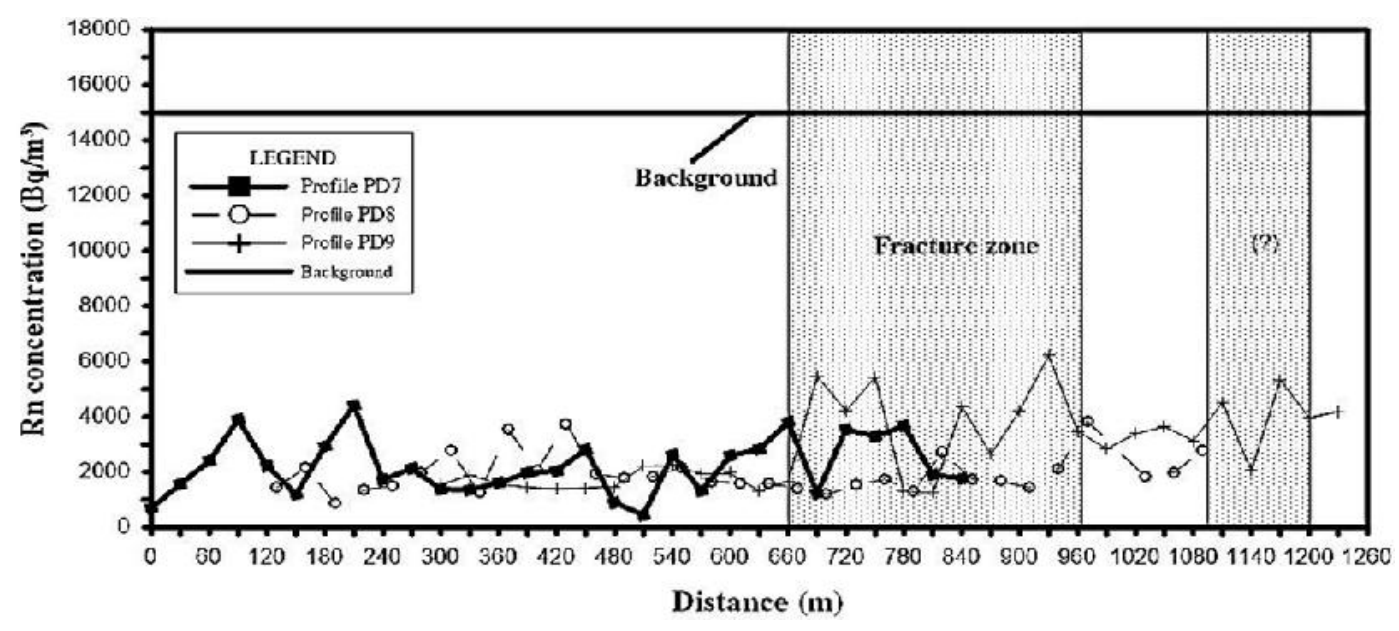

Figure 18. Combined graphic of radon concentrations at tectonic frature zone Suoi Tam Lang, showing increased radon concentrations within fracture zone in profiles PD7, PD8 and PD9 
Vietnam Journal of Earth Sciences, 39(1), 27-46

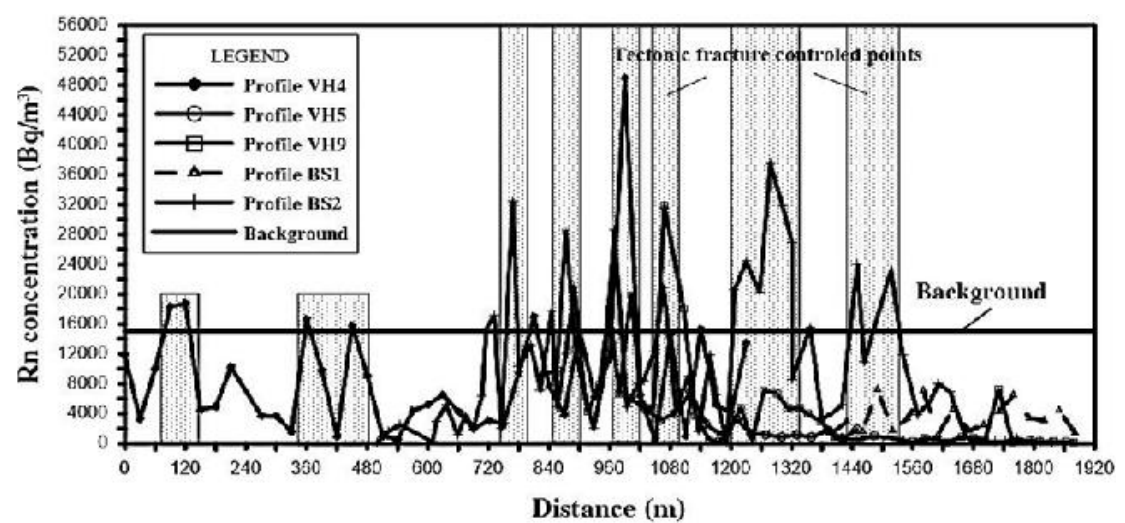

Figure 19. Combined graphic of radon concentration in Thai An area. Increasing of radon concentrations in profiles VH4, VH5, VH9, BS1 and BS2 recognized presence of series of fracture zones (see text for details)

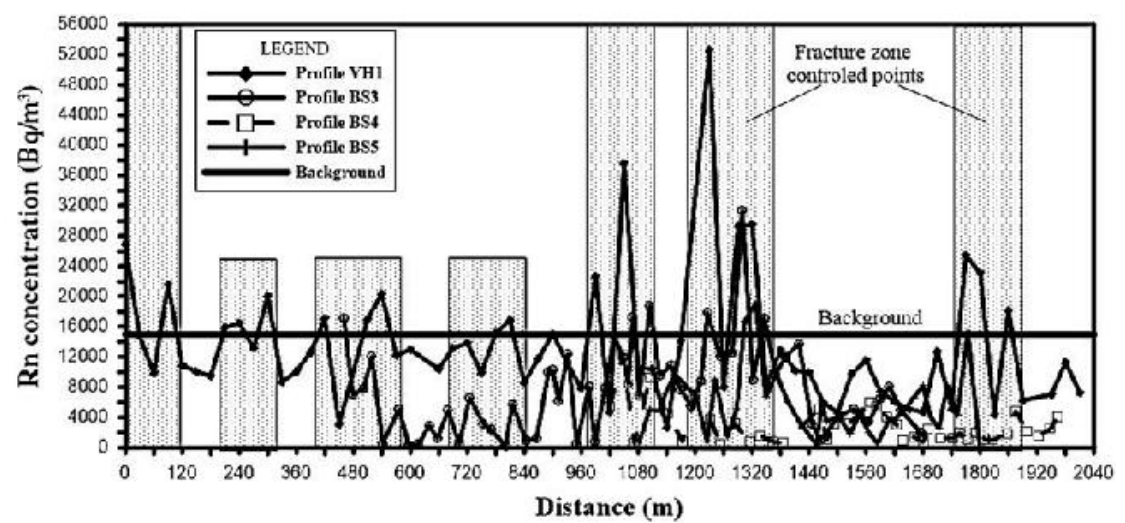

Figure 20. Combined graphic of radon concentrations in Tram Bang area. Increasing of radon concentrations in profiles VH1, BS3, BS4 and BS5 recognized presence of series of fracture zones (see text for details)

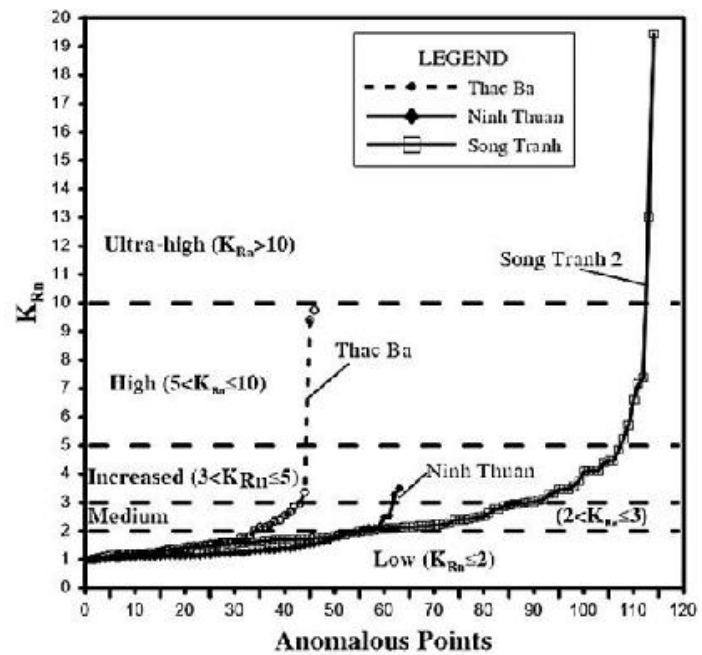

Figure 21. Radon activity indexes $\left(\mathrm{K}_{\mathrm{Rn}}\right)$ of of radon anomalous points Thac Ba, Ninh Thuan and Song Tranh 2 areas 
Pham Tich Xuan, et al./Vietnam Journal of Earth Sciences 39 (2017)

\section{Conclusions}

The results of soil radon gas measurements in 3 different areas showed differences in expression levels of fault activity as follows:

In the Thac $\mathrm{Ba}$ hydropower plant area, Song Chay fault shows clear activity expression and right slip motion in recent time with maximum $\mathrm{KRn}=9.75$ (high level).

In the Song Tranh 2 hydropower plant area, faults showing clear activity expression in recent time are Hung Nhuong - Ta Vy, Song Tra Bong and some high order faults with maximum KRn reached 20.16 (ultra-high level). Distribution of anomalous points with $\mathrm{K}_{\mathrm{Rn}}$ at increased or higher levels characterized by their focusing or in the segments, where these sub-parallel faults changed to northwest - southeast direction, or in their intersections with higher order northwest - southeast faults. Such distribution of anomalies also showed that the northwest - southeast faults are active.

In the areas where nuclear power plants Ninh Thuan $1 \& 2$ planned to build, the expressions of fault activity are not clear, although it is assumed that fault activity expression ranging between medium to low levels of $K_{R n}$ indexes $\left(K_{R n} \preceq 3\right)$.

These results are consistent with previously reported results acquired for the mentioned faults by other methods.

The studies of activity of tectonic faults using soil radon gas method had been carried out in different tectonic structure areas having different geological characteristics, but the obtained results are consistent with the results of previous studies. It confirms the effectiveness and capability of soil radon gas geochemistry in studying active tectonic faults and should be further developed and applied for other faults.

\section{Acknowledgements}

Soil radon gas data of the areas expected to build nuclear power plants Ninh Thuan $1 \& 2$ and hydropower plant Song Tranh 2 area were obtained by the authors in framework of National Projects "Study and evaluation of active faults for the approval of construction planning for nuclear power plant in Ninh Thuan province", coded 01/2012 and "Study on impact of seismotectonics to the stability of Song Tranh 2 hydropower plant, Bac Tra My region, Quang Nam province”, code 02 2012/HĐ - ĐTĐL.

\section{References}

Al-Hilal M., Al-Ali A., 2010. The role of soil gas radon survey in exploring unknown subsurface faults at Afamia B dam, Syria. Radiat. Meas, 45, 219-224.

Amponsah, P., Banoeng-Yakubo, B., Andam, A., Asiedu, D., 2008. Soil radon concentration along fault systems in parts of south eastern Ghana. J. Afr. Earth Sci. 51, 39-48.

Asumadu-Sakyi A.B., Fletcher J.J., Oppon O.C., Quashie F.K., Wordson D.A., Adjei C.A., Amartey E.O., Darko E.O. and Amponsah P., 2011. Preliminary Studies on Geological Fault Location Using Solid State Nuclear Track Detection. Research Journal of Environmental and Earth Sciences, 3(1), 24-31.

Baubron, J.-C., Rigo, A., Toutain, J.-P., 2002. Soil gas profiles as a tool to characterize active tectonic areas: the Jaut Pass example (Pyrenees, France). Earth Planet. Sci. Lett, 196, 69-81.

Burton, M., Neri, M., Condarelli, D., 2004. High spatial resolution radon measurements reveal hidden active faults on Mt. Etna. Geophys. Res. Lett, 31, L07618.

Ciotoli, G., Etiope, G., Guerra, M. \& Lombardi, S., 1999. The detection of concealed faults in the Ofanto basin using the correlation between soil gas fracture surveys. Tectonophysics, 299(3-4), 321-332.

Ciotoli, G., Lombardi, S. \& Annunziatellis, A., 2007. Geostatistical analysis of soil gas data in a high seismic intermontane basin: Fucino Plain, central Italy. J. Geophys. Res., 112, B05407, doi:10.1029/2005JB004044.

Font, L., Baixeras, C., Moreno, V., Bach, J., 2008. Soil radon levels across the Amer fault. Radiat. Meas, 43, 319-323.

Geological and Mineral Resources Map of Viet Nam on 1:200,000, 2005. Published by Department of Geol- 
Vietnam Journal of Earth Sciences, 39(1), 27-46

ogy and Minerals of Viet Nam, Ha Noi, Lists: Yen Bai (F-48-XXI), Tuyen Quang (F-48-XXII), Quang Ngai (D-49-VII\&VIII), Hoi An (D-49-I), Da Lat Cam Ranh (C-49-I\&II).

Ghosh D., Deb A. and Sengupta R., 2009. Anomalous radon emission as precursor of earthquake. J. Appl. Geophys., 69, 67-81.

González-Díez, A., Soto, J., Gómez-Arozamena, J., Bonachea, J., Martínez-Díaz, J.J., Cuesta, J.A.,Olague, I., Remondo, J., Fernández Maroto, G., Díaz de Terán, J.R., 2009. Identification of latent faults using a radon test. Geomorphology, 110, 11-19.

Haerudin N, Wahyudi, Munadi S., Suryanto W., 2013. A Soil Gas Radon Survey to Determine Fault at Southern Part of Rajabasa Geothermal Field, Lampung Indonesia. International Journal of Engineering \& Technology IJET-IJENS, 13(1), 75-81.

Hauksson E., 1981. Radon content of groundwater as an earthquake precursor: evaluation of worldwide data and physical basis. J. Geophys. Res., 86, 9397-9410.

Ioannides, K., Papachristodoulou, C., Stamoulis, K., Karamanis, D., Pavlides, S., Chatzipetros, A., Karakala, E., 2003. Soil gas radon: a tool for exploring active fault zones. Appl. Radiat. Isot, 59, 205-213.

Israel H. and Bjornsson S., 1967. Radon (Rn-222) and thoron (Rn-220) in soil air over faults. Z. Geophys, 33, 48-64.

Kemski, J., Siehl, A., Stegemann, R., ValdiviaManchego, M., 2001. Mapping the geogenic radon potential in Germany. Sci. Total Environ, 272, 217-230.

King C.Y., 1978. Radon emanation on San Andreas fault. Nature, 271, 516-519.

King, C.Y., King, B.S., Evans, W.C., 1996. Spatial radon anomalies on active faults in California. Appl. Geochem, 11, 497-510.

Laskar I., Phukon P., Goswami A.K., Chetry G. and Roy U.C., 2011. A possible link between radon anomaly and earthquake. Geochemical Journal, 45, 439-446.

Lombardi, S., Voltattorni, N., 2010. Rn, He and $\mathrm{CO}_{2}$ soil gas geochemistry for the study of active and inactive faults. Appl. Geochem, 25, 1206-1220.

Moussa M.M., Arabi A-G. M. E., 2003. Soil radon survey for tracing active fault: a case study along QenaSafaga road, East Desert, Egypt. Radiat. Meas, 37, 211-216.
Papastefanou C., 2010. Variation of radon flux along active fault zones in association with earthquake occurrence. Radiat. Meas, 45, 943-951.

Nguyen Dang Tuc, 2000. Kinematic characteristics of the Red River - Chay River fault zone in Cenozoic. Journal of Sciences of the Earth, 22, 174-180 (in Vietnamese).

Nguyen Van Pho, Nguyen Trong Yem, 1996. Gas geocchemical approach in study of the activity of Red river fault system. Journal of Geology, Ha Noi, series A, 236, 9-10.

Nguyen Van Pho, Hoang Tuyet Nga, 1996. Some results of the micro geodynamic maping in Thac $\mathrm{Ba}$ area by using of nuclear track detector method. In Geology Resources, Sci. and Tech. Publishing house, Ha Noi, 1, 187-191.

Nguyen Van Pho, Hoang Thi Tuyet Nga, Doan Thi Thu Tra, 1999. Study on the stability of Thac Ba hydrpopower dam by using nuclear track detector method. Journal of Geology, Ha Noi, Series B, 1314, 270-271.

Nguyen Van Pho, Hoang Thi Tuyet Nga, Nguyen Trung Minh, Doan Thi Thu Tra, Vu Manh Long, Le Thanh Chung, Nguyen Dinh Xuyen, Pham An Cuong, 2004. Results of radon continueous mesurments in soil gas at the North-Western area. Journal of Sciences of the Earth, 26, 653-656 (in Vietnamese).

Nguyen Trong Yem, 1996. Regimes of tectonic stress field during Cenozoi in Vietnam. Journal of Geology, Ha Noi, series A, 236, 1-6.

Reimann C., Filzmoser P., Garrett R.G., 2005. Background and threshold: critical comparison of methods of determination. Science of the Total Environment, 346, 1-3, 1-16.

Richon P., Klinger Y., Tapponnier P., Li C.X., Van Der Woerd J., Perrier F., 2010. Measuring radon flux across active faults: Relevance of excavating and possibility of satellite. Radiation Measurements, 45, 211-218.

Riggio A., and Santulin M., 2015. Earthquake forecasting: a review of radon as seismic precursor. Bollettino di Geofisica Teorica ed Applicata, 56(2), 95-114.

Seminsky K.Zh., Demberel S., 2013. The first estimations of soil-radon activity near faults in Central Mongolia. Radiation Measurements, 49, 19-34.

Swakón, J., Kozak, K., Paszkowski, M., Gradzinski, R., Loskiewicz, J., Mazur, J., Janik, M., Bogacz, J., 
Pham Tich Xuan, et al./Vietnam Journal of Earth Sciences 39 (2017)

Horwacik, T., Olko, P., 2004. Radon concentration in soil gas around local disjunctive tectonic zones in the Krakow area. J. Environ. Radioact, 78, 137-149.

Tanner, A.B., 1980. Radon migration in the ground: A supplementary review, in Gesell, T.F., and Lowder, W.M., eds., Natural Radiation Environment III: U.S. Dept. Energy Rept. CONF-780422, 1, 5-56.

Toutain J.P., Baubron J.C., 1999. Gas geochemistry and seismotectonics: a review. Tectonophysics 304, 1-27.

Tran Trong Hue, 1996. First results of research present geodynamics by soil gas radon method. In Geology Resource, Ha Noi, 1, 179-185.

Tran Trong Hue, 1999. Characteristics of radon radioactive gas in Song Ma fault zone. Journal of Sciences of the Earth, 123-128.

Tung S., Leung J. K. C., Jiao J. J., Wiegand J., Wartenberg W., 2013. Assessment of soil radon potential in Hong Kong, China, using a 10-point evaluation system. Environmental Earth Sciences, 68(3), 679-689.
Tran Van Duong, Tran Trong Hue, 1996. Some results of the investigation active faults in the South Central Viet Nam by radon method. Journal of Science of the Earth, 18, 276-288.

Tran Van Tri, Vu Khuc et al., 2009. Geology and earth resources of Viet Nam. Publishing House for Science and Technology, Ha Noi, 645.

Utkin V.I., Yurkov A.K., 2010. Radon as a tracer of tectonic movements. Russian Geology and Geophysics, 51, 220-227.

Wakita H., Nakamura Y., Notsu K., Noguchi M. and Asada T., 1980. Radon anomaly: a possibile precursor of the 1978 Izu-Oshimakinkai earthquake. Sci., 207, 882-883.

Walia V., Mahajan S., Kumar A., Singh S., Singh Bajwa B., Dhar S., Yang T.F., 2008. Fault delineation study using soil-gas method in the Dharamsala area, NW Himalayas, India . Radiat. Meas, 43, 337-342.

Wang X., Li Y., Du J., Zhou X., 2014. Correlations between radon in soil gas and the activity of seismogenic faults in the Tangshan area, North China. Radiation Measurements, 60, 8-14. 